\title{
Recovery of Phytase Produced by Solid-state Fermentation on Citrus Peel
}

\author{
Daniel Ernesto Rodríguez-Fernández ${ }^{1}$, José Angel Rodríguez-León ${ }^{1}$, Júlio Cesar de \\ Carvalho $^{1}$, Vanete Thomaz-Soccol ${ }^{1,2}$, José Luis Parada ${ }^{2}$ and Carlos Ricardo Soccol ${ }^{{ }^{*}}$ \\ ${ }^{1}$ Divisão de Engenharia de Bioprocessos e Biotecnologia; Universidade Federal do Paraná Federal 81531-970; \\ Curitiba - PR - Brasil. ${ }^{2}$ Divisão de Biotecnologia Industrial; Universidade Positivo; 81280-330; Curitiba - PR - \\ Brasil
}

\begin{abstract}
The extraction of phytase produced by solid-state fermentation of citrus peel was studied employing a multistage leaching process. It was observed that the extracts containing EDTA retained over $90 \%$ of phytase activity at room temperature after $24 \mathrm{~h}$ after the leaching. A fractional design $2^{2}$ (with 4 replicates at the central point) was carried out for testing the $\mathrm{pH}$ and agitation as process independent factors. Only the interaction between the pH and agitation showed a significant influence. These factors were optimized with a central composite design. Agitation at $300 \mathrm{rpm}$ and $\mathrm{pH}$ at 5.0 were the best conditions to extract the enzyme from solid matrix. The modeling of the process indicated that diffusivity of the enzyme in the solvent was the controlling mechanism. The corresponding kinetic constant and saturation concentration in this process were $0.89 \mathrm{~min}^{-1}$ and $4.0 \mathrm{IU} / \mathrm{mL}$, respectively. The multistage process indicated that after two steps, it was possible to recover $85 \%$ of total enzyme produced.
\end{abstract}

Key words: leaching, recovery multistage, phytase, solid state fermentation, kinetic models

\section{INTRODUCTION}

The inclusion of enzymes in the formulation of feeding diets for mono-gastric animals have increased in recent times (Cowieson et al., 2006; Bedford and Schultze, 1998). The purpose of these additives deals with the aim to make the diets more efficient in terms of animal weight gain against the amount of diets consumed, and also, to reduce the negative impact of large-scale animal production over the environment. In this regard, the employment of phytase in the diary food of mono-gastric animals is especially important (Vohra et al., 2003; Wodzinski et al., 1996).
Phytase is a generic term used to describe the enzymes that are able to hydrolyze the phosphomonoester bonds from phytic acid (myoinositol 1.2.3.4.5.5-hexakis dihydrogen phosphate), thereby liberating inorganic phosphates (Mullaney and Ullah, 2003). Phytases are considered important additive in large-scale mono-gastric animal production, mainly pigs and poultry farms, because they are able to make the phosphorus present in phytate molecule digestible. This effect over the phosphorus allows decreasing the use of inorganic phosphorus source in the animal diets, giving two important advantages on animal production. The first advantage is reducing or eliminating the organic phosphorus presents in

*Author for correspondence: soccol@ufpr.br 
the animal feed; second advantage is on the environment, avoiding eutrophication of freshwater or seawater (Durmand and Jondreville 2007; Bogar et al., 2003). However, the high price of commercial phytase, which adds up US\$2-3 per metric ton of the feed, is the main problem to the widespread application of phytase as feed supplement. Also, majority of the commercial phytase is produced by submerged fermentation, which is an expensive process (Bogar et al., 2003). There have been reports on the use of filamentous fungi for the production of phytase in solid-state fermentation (SSF) (Spier et. al. 2008, Bogar et. al, 2003). One of the main advantages of SSF lies in the fact that agro and food industrial residues can be employed as substrates directly or with only a mild pretreatment (Pandey et al., 2001). When enzymes are produced by SSF, the first step for the recovery or purification process is the leaching or liquid/solid extraction (Rodríguez-Fernandez, 2004). However, there are just a few papers dealing with the leaching of metabolites from a solid-state fermented matrix (Ikari and Mitchell, 1996; Castilho et. al., 1999; 2000; Palit and Banerjee, 2001; 2010; Heck et. al., 2005; Díaz et. al. 2007) and none considering the leaching of phytase form a solid-state fermented matrix. Thus, the aim of the present work was to study the extraction of phytase produced in SSF on a citrus peel medium.

\section{MATERIALS AND METHODS}

\section{Microorganism and strain conservation}

A strain of Aspergillus niger F3 was used in this work. The culture was grown in Czapeck medium (agar slants) by incubating at $30^{\circ} \mathrm{C}$ for seven days. The slants were preserved at $4-8^{\circ} \mathrm{C}$.

\section{Inoculum preparation}

Ten grams ground dried citrus peel was mixed with $100 \mathrm{~mL}$ of hot distilled water for 15 minutes and after cooling to room temperature, the solution was filtered. The filtrate was diluted at 1:10 with distilled water, followed by the addition of $0.3 \mathrm{~g}$ $\mathrm{NH}_{4} \mathrm{NO}_{3}, \mathrm{pH}$ adjustment at 5.0 and was autoclaved at $121^{\circ} \mathrm{C}$ for 15 minutes. After cooling, this was inoculated with the spores of fungal culture and incubated in a shaker at $30^{\circ} \mathrm{C}$ and $120 \mathrm{rpm}$ for 96 h.

\section{Solid-state fermentation}

The dried citrus peel ( $75 \%$ of peel had a particle size ranging from $0.8 \mathrm{~mm}$ to $2 \mathrm{~mm}$, and the other $25 \%$ had a particle size between $2-3 \mathrm{~mm}$ ) was supplemented with (\% dry wt basis) $\mathrm{NH}_{4} \mathrm{NO}_{3} 0.43$; $\mathrm{NaSO}_{4} 0.021 ; \mathrm{MgSO}_{4} .7 \mathrm{H}_{2} \mathrm{O} 0.077 ; \mathrm{ZnSO}_{4} .7 \mathrm{H}_{2} \mathrm{O}$ $0.042 ; \mathrm{KCl} 0.162 ; \mathrm{Ca}(\mathrm{OH})_{2} \quad 0.011$. Water was added to the medium to obtain $60 \%$ initial humidity. Inoculation was made in 1:10 (v/w) of mycelia grown as above with biomass concentration $15 \mathrm{~g} / \mathrm{L}$. Fermentations were carried out in a static drum bioreactor with $2 \mathrm{Kg}$ substrate and aeration of $1 \mathrm{VKgM}$ (defined as 1 liter of air per kilogram of moist medium per minute; $\mathrm{L} \mathrm{kg}^{-1}$ $\min ^{-1}$ ) (Rodríguez-Fernández, 2009).

\section{Phytase activity}

Phytase activity was determined using a modified method as described by Greiner and Farou (2007). Enzyme assay was carried out at $50^{\circ} \mathrm{C}$ in $350 \mu \mathrm{L}$ of $100 \mathrm{mM}$ sodium citrate buffer $(\mathrm{pH}$ 3.0) containing $875 \mathrm{nmol}$ sodium phytate. The enzymatic reaction was started by adding $50 \mu \mathrm{L}$ of enzyme solution to the assay mixture. After incubating at $50^{\circ} \mathrm{C}$ for $15 \mathrm{~min}$, the liberated phosphate was measured according to the ammonium molybdate method (Heinonen and Lahti, 1981). Then, $1.5 \mathrm{~mL}$ of freshly prepared solution of acetone/5 N H2SO4/10 mM ammonium molybdate $(2: 1: 1 \mathrm{v} / \mathrm{v})$ and $100 \mu \mathrm{L} 1.0$ $\mathrm{M}$ citric acid were added to the assay mixture. Any cloudiness that might have appeared was removed by centrifugation prior to the measurement of absorbance at $355 \mathrm{~nm}$. One international unit (IU) of phytase activity is expressed as $1 \mu \mathrm{mol}$ phosphate liberated per $\mathrm{mL}$ per $\min \left(\mu \mathrm{mol} \mathrm{mL} \mathrm{m}^{-1}\right.$ $\left.\min ^{-1}\right)$. Blanks were run by the addition the of ammonium molybdate solution prior to adding the enzyme to the assay mixture.

\section{Leaching of enzymes}

Extracts were prepared by employing a mechanical agitator FISATOM Model 713D in a beaker (1000 $\mathrm{ml}$ of working volume) using a solid/liquid ratio of $1 / 25 \mathrm{~g} / \mathrm{mL}$, considering dry wt basis of fermented matter.

\section{Influence of anions on the extraction}

The effect of anions $\left(\mathrm{Cl}^{-}, \mathrm{SO}_{4}{ }^{-2}, \mathrm{NO}_{3}{ }^{-1}\right.$, citrate anion, acetate anion and EDTA) on enzyme 
activity was investigated by the addition of acid solutions containing these anions to the solvent for $30 \mathrm{~min}$ at room temperature (approximately $25^{\circ} \mathrm{C}$ ). The EDTA was added at a concentration of $50 \mu \mathrm{L}$. Distilled water was considered as the control. The solid-liquid relation was fixed at $25 \mathrm{~g} / \mathrm{ml}$ on dry wt basis.

\section{Experimental designs}

An initial $2^{2}$ factorial plan with four repetitions of the central point was employed to determine the influence of $\mathrm{pH}$ (4.5 and 6.5) and agitation (450 and 150) on phytase extraction with the central point being $\mathrm{pH} 5.0$ and $300 \mathrm{rpm}$, respectively (Montgomery, 2005).

Table 1- Experimental range and levels of independent variables studied using a two level fractionated factorial design $\left(2^{2}\right)$ with replicates at central point in terms of actual and coded factors.

\begin{tabular}{ccccc}
\hline \multirow{2}{*}{ Factors } & Corresponding Variable & \multicolumn{3}{c}{ Coded level of variable } \\
\cline { 3 - 5 } & & -1 & 0 & 1 \\
\hline $\mathrm{A}$ & $\mathrm{pH}$ & 3.5 & 5.0 & 6.5 \\
$\mathrm{~B}$ & Agtation $(\mathrm{rpm})$ & 150 & 300 & 450 \\
\hline
\end{tabular}

After establishing the influence of the above variables, the factorial design was extended to a Central Composite Design considering the results obtained, plus four axial points with values of $\mathrm{pH}$ of 2.9 and 7.1 and agitation of 90 and $510 \mathrm{rpm}$.
This kind of design allows the optimization of the dependent variable if there is a non-lineal zone in the range analyzed (Montgomery, 2005). All runs lasted 30 minutes.

Table 2- Experimental range and levels of independent variables studied using a CCD in terms of actual and coded factors.

\begin{tabular}{ccccccc}
\hline \multirow{2}{*}{ Factor } & \multirow{6}{*}{ Units } & $-\alpha$ & -1 & 0 & 1 & $\alpha$ \\
\cline { 3 - 7 } & & 2.9 & 3.5 & 5.0 & 6.5 & 7.1 \\
$\mathrm{nyH}$ & & 89 & 150 & 300 & 450 & 520 \\
\hline Agitation & $(\mathrm{rpm})$ & & & & & \\
\hline
\end{tabular}

\section{RESULTS AND DISCUSSION}

\section{Effect of anions on the recovery of phytase}

The influence of anions on the phytase activity was carried out taking water as control at room temperature during 30 minute. The control sample had an activity of $3.57 \mathrm{IU} / \mathrm{ml}$. Figure 1 showed that none of the anions used in the study had an activating effect when used at a concentration of $30 \mathrm{mM} ; \mathrm{NO}_{3}{ }^{-}$showed significant inhibitory effect on phytase activity. Only EDTA (3.69 IU/ml) had better results when compared with the control because EDTA tended to chelate metal ions, which inhibited the enzyme activity. Furthermore, the growth medium contained different ions that were considered to be inhibitors of enzyme activity. Therefore, the enzyme stability was tested after 24 $\mathrm{h}$ at room temperature. The sample with EDTA conserved approximately $90 \%$ of the initial activity, whereas the control sample lost nearly $33 \%$ of its initial activity. This positive effect over phytase activity by the EDTA added could be related with the EDTA ability for inhibiting the proteolytic enzymes and with the chelation of many ions present in the solution that could have inhibited the phytase activity. 


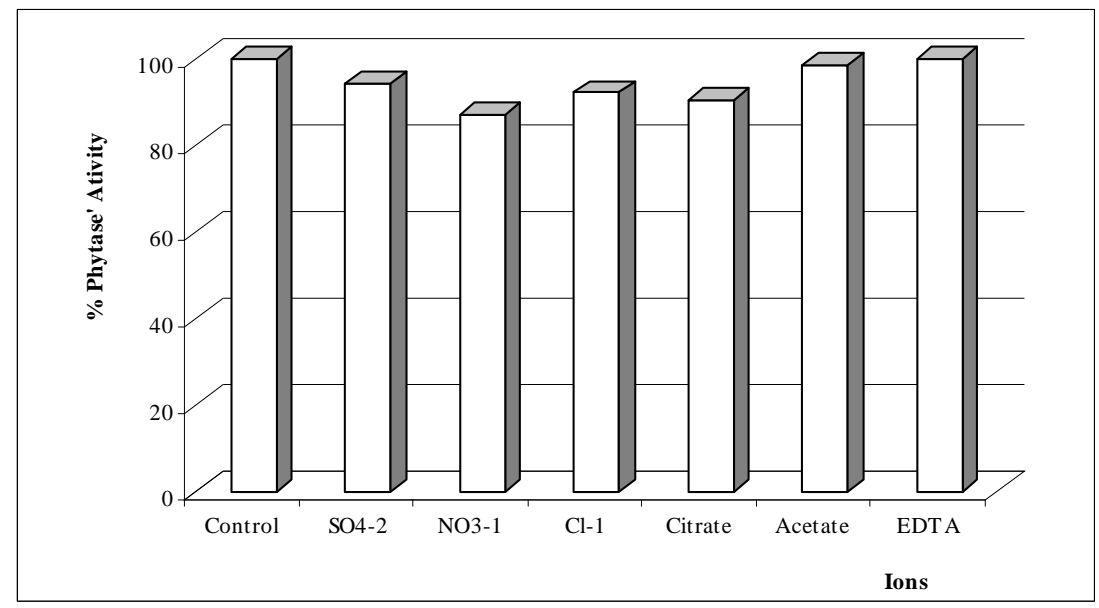

Figure 1 - Effect of several anions on phytase activity during the extraction from solid matrix fermented.

\section{Statistical analysis for factorial design $\mathbf{2}^{2}$}

After establishing the composition of the solvent to leach the phytase from solid matrix, different levels of $\mathrm{pH}$ and agitation were tested through a $2^{2}$ factorial design. The response matrix $(\mathrm{Y})$ obtained from the experiments developed in the fractionated factorial plan $2^{2}$ is shown in Table 3 . The highest activities obtained in the corresponded to runs made at central point. ANOVA was performed to obtain the significant coefficients corresponding in terms of coded factors and to validate the regression model. In Table 4 , the results for the values and discrimination of coefficients $\left(\beta_{0}, \beta_{1}, \beta_{2}\right.$ and $\beta_{12}$ ) consequent to the independent factors are shown. The ANOVA analysis showed that the interaction between $\mathrm{pH}$ and agitation was significant at a $95 \%$ confidence level; moreover, independent factor had no significant influence on the phytase recovery. The statistical model obtained in Table 3, indicated a significant lack of fit of the model obtained. The coefficient regression was 0.6017 . This significant lack of fit suggested that a non-linear model could adjust better in the range analysed and that there might be a zone of optimal conditions. This optimal point would be better represented by a second order model fixed in the range studied; it could be a point of maximum.

Table 3 - Response matrix (Y) of the factorial plan $2^{2}$ developed for the phytase lixiviation.

\begin{tabular}{cccc}
\hline Run & $\mathbf{p H}$ & Agitation $(\mathbf{r p m})$ & Act. $(\mathbf{U} / \mathbf{m L})$ \\
\hline 1 & 3.5 & 150 & 3.462 \\
2 & 6.5 & 150 & 3.277 \\
3 & 3.5 & 450 & 3.362 \\
4 & 6.5 & 450 & 3.502 \\
PC1 & 5.0 & 300 & 3.911 \\
PC2 & 5.0 & 300 & 3.880 \\
PC3 & 5.0 & 300 & 3.928 \\
PC4 & 5.0 & 300 & 3.831 \\
\hline
\end{tabular}

Table 4- Factor coefficients discrimination corresponding to the fractionated factorial design $2^{2}$.

\begin{tabular}{ccc}
\hline Fator & Coeficiente de Regressão & p \\
\hline Independent term $\left(\beta_{0}\right)$ & 3.644 & $0.0000001^{*}$ \\
$\mathrm{pH}(\mathrm{L})\left(\beta_{1}\right)$ & -0.01122 & 0.635184 \\
Agitation $(\mathrm{L}) .\left(\beta_{2}\right)$ & -0.03118 & 0.240004 \\
Interation $\left(\beta_{12}\right)$ & 0.08106 & $0.032001^{*}$ \\
Lack of fit & - & $0.000518^{*}$ \\
\hline
\end{tabular}

\footnotetext{
* Significant variables and interactions.
} 
A central composite design based on the results of the factorial design was carried out to optimise the conditions for lixiviation. For this reason, four axial points were added as complementation and design a surface design to optimize the phytase activity in fresh extracts. The design and results are shown in Table 5. The analysis of variance was performed to validate the regression model. The regression coefficients and $p$-values are presented in Table 6. The statistical model accounted for $97.72 \%$ of the response. Figure 2 shows the surface response and the optimum (maximum) point of phytase activity.The coordinates of the maximal point were at $\mathrm{pH} 5.0$ and $300 \mathrm{rpm}$. At this point, $3.91 \mathrm{IU} / \mathrm{mL}$ enzyme was obtained.

The matrix response corresponding to the considered Central Composite Design is reported in Table 6. The ANOVA allowed to establish the following statistical model with a $95 \%$ confident level:

$$
Y=0,03 X_{1} X_{2}-0,26 X_{1}^{2}-0,2 X_{2}^{2}
$$

Where :

$\mathrm{X}_{1}$ : codified values of $\mathrm{pH}$

$\mathrm{X}_{2}$ : codified values of agitation respectively.

Y: Phyatse activity $(\mathrm{U} / \mathrm{mL})$

Table 5 - Experimental design and response matrix (Y) corresponding to the CCD employed for the optimization of phytase recovery.

\begin{tabular}{cccc}
\hline Run & $\mathbf{p H}$ & Agitation $(\mathbf{r p m})$ & Act. $(\mathbf{U} / \mathbf{m L})$ \\
\hline 1 & 3.5 & 150 & 3.462 \\
2 & 6.5 & 150 & 3.277 \\
3 & 3.5 & 450 & 3.362 \\
4 & 6.5 & 450 & 3.502 \\
PC1 & 5.0 & 300 & 3.911 \\
PC2 & 5.0 & 300 & 3.880 \\
PC3 & 5.0 & 300 & 3.928 \\
PC4 & 5.0 & 300 & 3.831 \\
Ax1 & 2.9 & 300 & 3.365 \\
Ax2 & 7.1 & 300 & 3.230 \\
Ax3 & 5.0 & 90 & 2.894 \\
Ax4 & 5.0 & 510 & 3.417 \\
\hline
\end{tabular}

Table 6- Discrimination of the factor coefficients corresponding to the CCD.

\begin{tabular}{ccc}
\hline Fator & Coeficiente de Regressão & p \\
\hline Independent term $\left(\beta_{0}\right)$ & 3.864134 & $0.0000001^{*}$ \\
$\mathrm{pH}(\mathrm{L})\left(\beta_{1}\right)$ & -0.028114 & 0.133186 \\
$\mathrm{pH}(\mathrm{Q})\left(\beta_{11}\right)$ & -0.220867 & $0.000429^{*}$ \\
Agitation $(\mathrm{L})\left(\beta_{2}\right)$ & 0.002276 & 0.878957 \\
Agitationo $(\mathrm{Q})\left(\beta_{22}\right)$ & -0.162987 & $0.001057^{*}$ \\
Interation $\left(\beta_{12}\right)$ & 0.081057 & $0.032001^{*}$ \\
Lack of fit & - & 0.051091 \\
\hline
\end{tabular}

\section{Kinetic pattern of the PG leaching process}

After the initial conditions for the leaching of phytase were established, the kinetics of the process was studied. Figure 3 shows the leaching kinetic of phytase, which showed that the saturated enzyme concentration attained a value of 4.0 $\mathrm{IU} / \mathrm{ml}$, which was obtained in a mechanically stirred flask after 75 minutes of operation at the conditions established during the optimization of statistical model. 


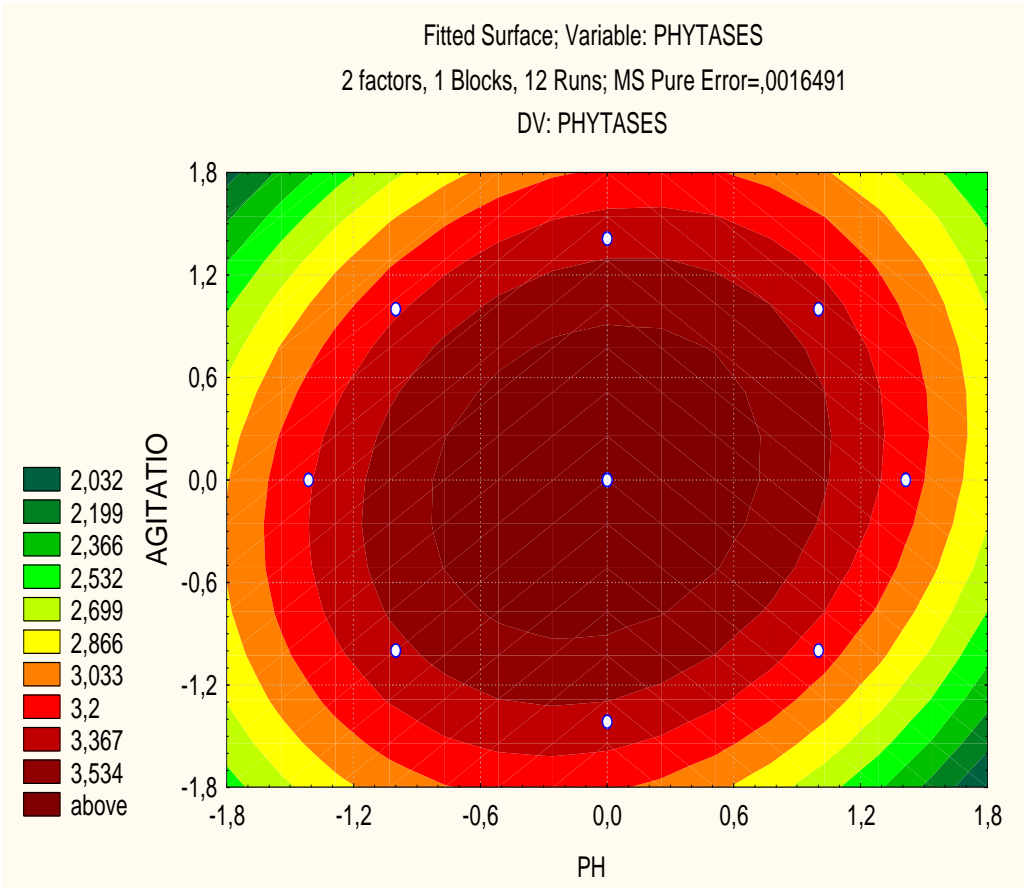

Figure 2 - Surface response corresponding to the CCD considering enzyme extraction as depending variable of $\mathrm{pH}$ and agitation.

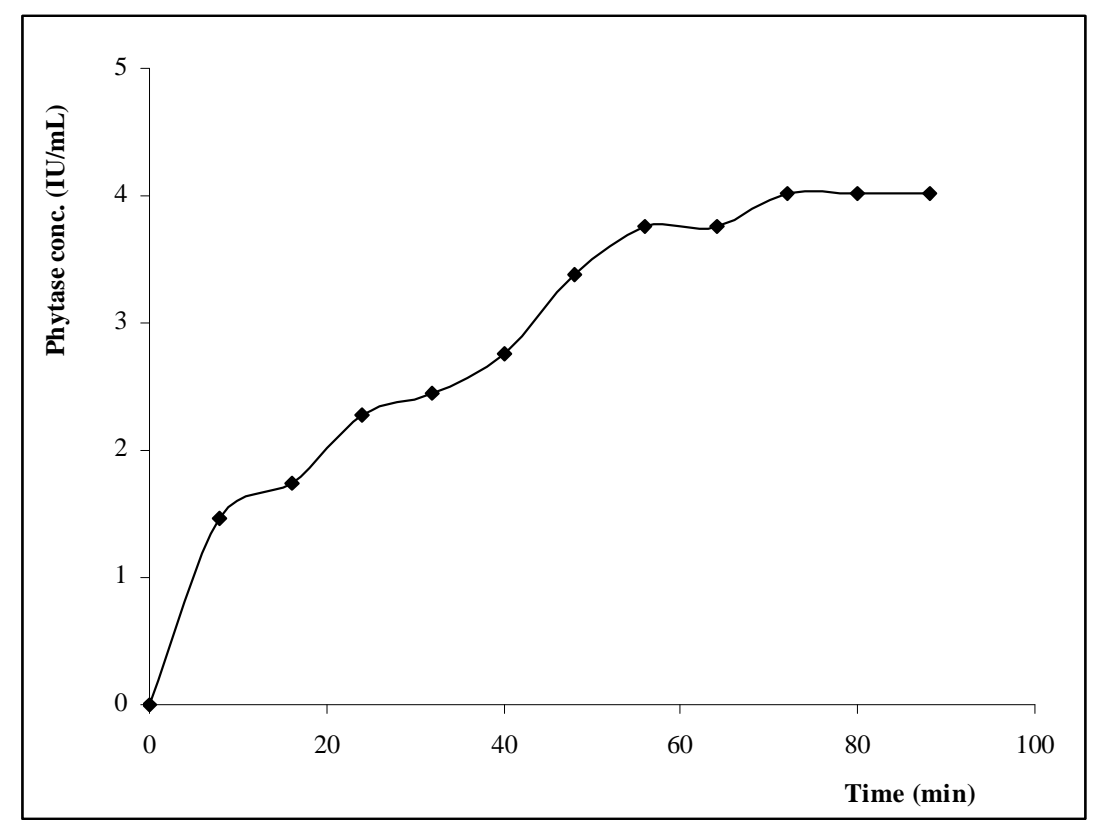

Figure 3 - Kinetics of phytase leaching from a solid fermented dried citrus pulp by an A. niger F3 matrix.

It was assumed that the leaching mechanism depends on factors such as the migration of the solute extracted from the surface of the solid matrix in the bosom of the solvent without interferences, the entrance of liquid into intraparticle spaces or pores of the matrix, the redistribution of solvent in the cell compartments and the expansion of the solid and the dissolution 
and/or degradation of the solutes. However, most of these transformations take part in the beginning of the extraction, when the solid matrix is added to the solvent, and then the diffusion of solute takes over. The basic equation for lixiviation processes is represented by a first order kinetic equation (Coulson and Richardson, 1981):

$C=C_{S}\left(1-e^{-k t}\right)$ where:

$\mathrm{k}$ : Leaching specific rate constant of $\left(\mathrm{min}^{-1}\right)$

C: Enzyme concentration (IU/ml)

$\mathrm{C}_{\mathrm{s}}$ : Saturated enzyme concentration (IU/ml)

$\mathrm{t}$ : Time (min)

Equation (1) can be represented in a linear form as:

$\ln \left(\frac{C_{s}-C}{C_{s}}\right)=-k t$

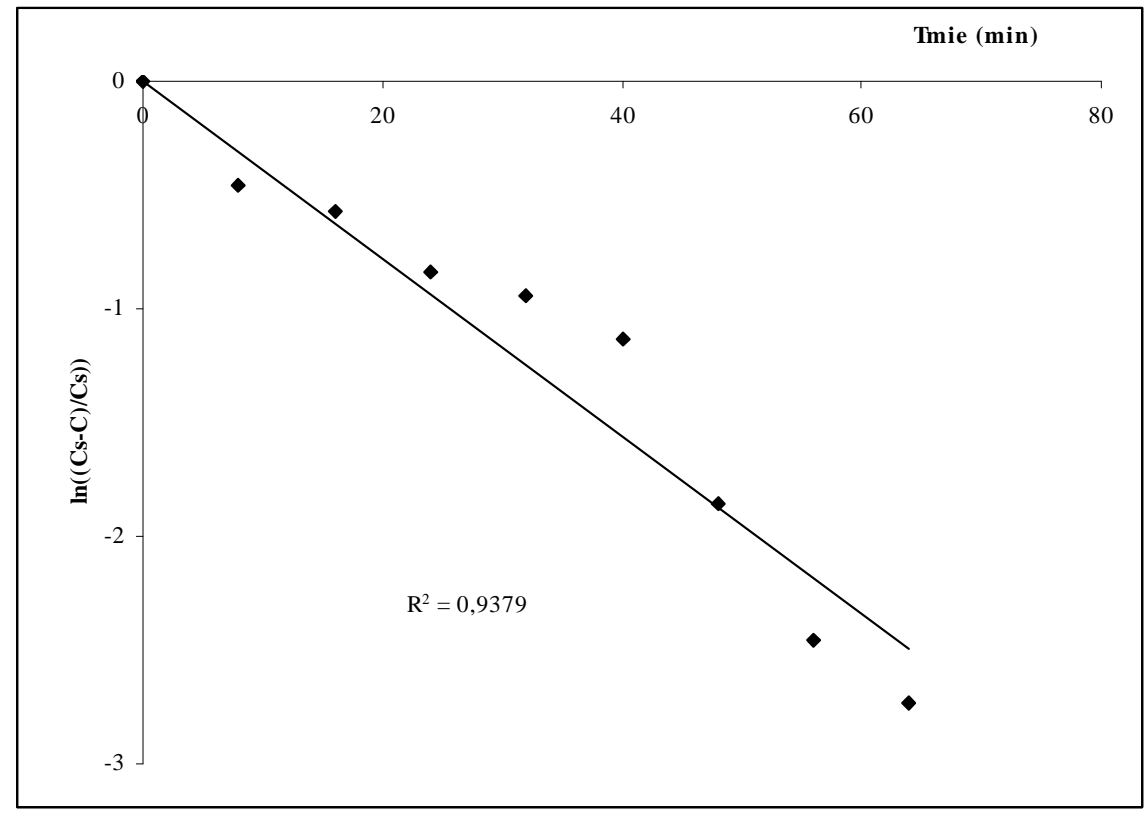

Figure 4 - Linear form of Equation (1) and estimated values for the parameters.

The kinetic constant of the process $(\mathrm{k})$ could be deduced from expression (2) by linear correlation of the data. Figure 4 expresses graphically the leaching data suitably plotted in logarithmic scale according Equation 3. A fair correlation of 0.9456 confirmed the validity of assumption that this process was controlled only by the migration of the extracted solute from the particle surface into the bulk solution without further interference, including that of the possible entry of the solvent into the particles. The model obtained to phytase leaching is given by:

$C=4,01\left(1-e^{-0,039 t}\right)$

\section{Study of the PG leaching process by a multistage process}

After studying and modeled mathematically the first step of extraction, it was decided to make several consecutive extractions to determine the quantity of phytase produced in the fermentation process. For this, four successive leaching steps were performed at a low solid-liquid ratio (1:25) with the residual solid from the preceding step. Each step lasted for $40 \mathrm{~min}$ at $300 \mathrm{rpm}$ and $25^{\circ} \mathrm{C}$. Figure 5 shows the concentration of phyatse in the solution. The first and second extraction steps had a phytase concentration over $3 \mathrm{IU} / \mathrm{mL}$ and the others steps showed a drastical drop in phytase 
concentration. The phytase concentrations obtained in the earlier steps were higher than 2.0 $\mathrm{IU} / \mathrm{mL}$, comparing feasibly with concentrations reported for those obtained by submerged fermentations, which reached $2.0 \mathrm{IU} / \mathrm{mL}$ as highest concentration for strain modified genetically to produce phytase (RodríguezFernández, 2009). This results indicated that one step leaching process for phytase at a solid-liquid ratio of 1:25 in dry basis resulted in an extraction of $44.79 \mathrm{IU} / \mathrm{g}$ on dry wt basis, with residual activity as high as $48.29 \mathrm{IU} / \mathrm{g}$ (Table 8 ). This value was more than the value obtained in a one step extraction. The concentration in each step diminished with successive steps, which indicated that the former kinetic patterns established were no longer valid and that the transport of the solute to the exterior of the particles or internal diffusion started to control the process.

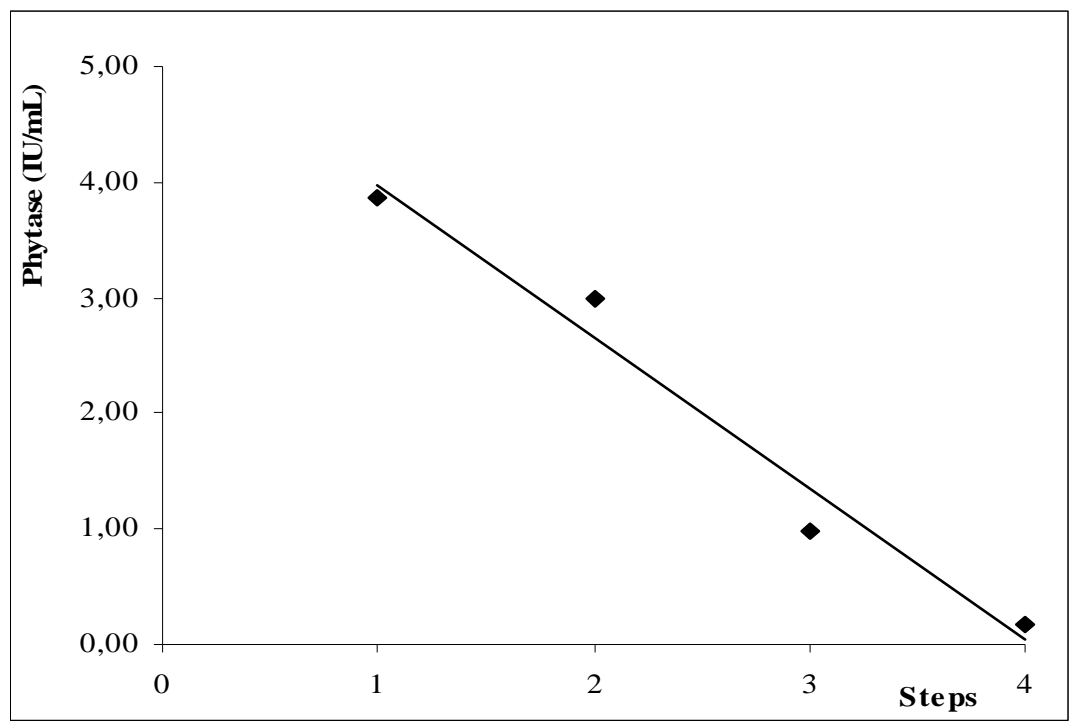

Figure 5 - Phyatse concentration obtained for each successive steps of recovery.

Table 8 - Results of PG leaching from a fermented dried citrus pulp by A.. niger F3 at six steps with a solid-liquid ratio of $1: 25$ for a dry basis.

\begin{tabular}{cccc}
\hline Step & $\begin{array}{c}\text { Phyatse in solvent. } \\
(\mathbf{I U} / \mathbf{m l})\end{array}$ & $\begin{array}{c}\text { Phytase extracted from solid } \\
\text { matrix. (IU/g) }(\mathbf{d . b} .)\end{array}$ & $\begin{array}{c}\text { Yield Phytase extracted } \\
\text { \% }\end{array}$ \\
\hline 1 & 3.86 & 44.79 & 48.12 \\
2 & 3.00 & 34.79 & 37.37 \\
3 & 0.99 & 11.44 & 12.29 \\
4 & 0.18 & 2.06 & 2.21 \\
\hline
\end{tabular}

As shown in Table 8, it was possible to recover approximately $85 \%$ of the phytase produced after two steps of extraction, indicating that two liquid extractions from a solid-state fermented substrate were better than equivalent to two submerged fermentations, emphasising one of the advantages of this type of fermentation. Furthermore, the entire phytase content in the solid fermented substrate after four steps was calculated to be 93.03 IU/g (dry wt basis), which was overlooked if it was considered at only one stage.

\section{CONCLUSIONS}

The lixiviation of phytase produced by solid-state fermentation of dried citrus peel was not influenced by the addition of ions for extraction improvement. However, the stability of the enzyme was improved by the addition of EDTA. The extraction of the enzyme was affected by the extremes of agitation and $\mathrm{pH}$ and this was controlled by external diffusion of the metabolite. If only one stage was used, there was a loss of 
more that $50 \%$ of the enzyme produced. The process could be improved by one or two more extraction stages, with the concentration obtained in the second step being as high as $75 \%$ of the value obtained in the first one. After two steps of extractions, it was possible to recover $85 \%$ of enzymes produced with higher concentration in the solution.

\section{RESUMO}

A extração de fitases produzidas por fermentação em estado sólido de polpa cítrica foi estudada utilizando um processo de extração sólido-líquido em varias etapas. A adição de EDTA permite manter durante 24 horas a temperatura ambiente 90\% da atividade inicial do caldo com a enzima extraída. Um planejamento fatorial $2^{2}$, com 4 replicas no ponto central, foi desenvolvido para testar os valores de ph e agitação convenientes para a extração das enzimas. A interação entre ambos os fatores foi estadisticamente significativa. A atividade da enzima foi otimizada nos valores onde o pH (5.0) e a agitação (350 rpm) resultaram ser as melhores condições para extrair a enzima da matriz sólida. $\mathrm{O}$ ajuste do modelo matemático obtido mostra que é possível considerar a difusividade como o mecanismo que controla o processo de transferência de massa. A constante cinética que descreve este processo e a concentração de saturação foram $0.039 \mathrm{~min}^{-1} \mathrm{e}$ $4.01 \mathrm{IU} / \mathrm{mL}$ respectivamente. A extração em varias etapas mostrou que nas duas primeiras etapas é possível recuperar $85 \%$ da fitase produzida.

\section{REFERENCES}

Bedford, M.R.; Schulze, H. (1998), Exogenous enzymes for pigs and poultry. Nutr Res Rev, 11, 91114

Bogar, B.; Szakacs, G.; Linden, J. C.; Pandey, A.; Tengerdy, R. P. (2003), Optimization of phytase production by solid substrate fermentation. $J$ Ind Microbiol Biotechnol, 30, 183-189

Castilho, L.R.; Medronho, R. A.; Alves, T.L.M. (1999), Recovery of pectolytic enzymes produced by solid state culture of Aspergillus niger. Process Biochem, 34, 181-186
Castilho, L.R.; Alves, T.L.M.; Medronho, R. A. (2000), Production and extraction of pectinases obtained by solid state fermentation of agroindustrial residues with Aspergillus niger. Bioresour Technol, 71, 45-50

Coulson, J. M.; Richardson; J. F. (1981), Ingeniería Química. Tomo II, Capítulo 10. Lixiviación. Ed: Editorial Reverté S. A. España

Cowieson, A.J.; Hruby, M.; Pierson E.E.M. (2006), Evolving enzyme technology: impact on commercial poultry nutrition. Nutr Res Rev, 19, 90-103

Díaz, A.B.; Caro, I.; de Ory, I.; Blandino, A. (2007), Evaluation of the conditions for the extraction of hydrolitic enzymes obtained by solid state fermentation from grape pomace. Enzyme Microb Technol, 41, 302-306

Dourmad, J.I.; Jondreville, C. (2007), Impact of nutrition on nitrogen, phosphorus, $\mathrm{Cu}$ and $\mathrm{Zn}$ in pigmanure, and on emissions of ammonia and odours. Livest Sci, 112; 192-198

Fadel, M. (2001), High-level xylanase production from sorghum flour by a newly isolate of Trichoderma harzianum cultivated under solid state fermentation. Ann Microbiol, 51, 61-78

Greiner, R.; Farouk A.E. (2007), Purification and characterization of a bacterial phytase whose properties make it exceptionally useful as a feed supplement. The Protein Journal, 26, 467-474

Heck, J.X., Hertz, P.F.; Ayub, M.A.Z. (2005), Extraction optimization of xylanases obtained by solid-state cultivation of Bacillus circulans BL53. Process Biochem, 40, 2891-2895

Heinonen, J.K.; Lahti, R. J. (1981), A new and convenient calorimetric determination of inorganic orthophosphate and its application to the assay of inorganic pyrophosphatase. Anal Biochem, 113, 313317

Ikasari, L.; Mitchell, D.A. (1996), Leaching and characterization of Rhizopus oligosporus acid protease from solid-state fermentation. Enzyme Microb Technol, 19, 171-175

Montgomery, D.C. (2005), Design and Analysis of Experiments (2005), Ed. John Wiley \& Sons. New York.

Mullaney, E.J.; Ullah, A.H.J. (2003), The term phytase comprises several different classes of enzymes. Biochem Biophys ResCommun, 312, 179-184

Pandey A, Soccol, C. R., Rodriguez-Leon, J. A. \& Nigam, P. (2001), Solid state fermentation in biotechnology: fundamentals and applications. Ed. Asiatech Publishers Inc. New Delhi

Palit, S.; Banerjee, R. (2001), Optimization of extraction parameters for recovery of a-amylase from the fermented bran of Bacillus circulans GRS313. Braz Arch Biol Technol, 44,107-111 
Rodríguez-Fernández, D.E. (2004), Estudio de la lixiviación de la enzima polimetilgalacturonasa (PMG) obtenida en un proceso de fermentación en estado sólido. Ms. Sci Thesis., Instituto Superior Poliyécnico José Antonio Echevarría (ISPJAE), La Habana, Cuba.

Rodríguez-Fernández, D. E. (2009), Desenvolvimento de um bioprocesso por fermentação em estado sólido para produzir e recuperar enzimas de interesse comercial. PhD Thesis, Universidade Federal do Paraná, Brasil

Spier, M.R.; Greiner, R.; Rodriguez-León, J.A.; Woiciechowski, A.L.; Pandey, A.; Soccol, V.T.; Soccol, C.R. (2008), Phytase Production Using Citric Pulp and Other Residues of the Agro-Industry in SSF by Fungal Isolates. Food Technol Biotechnol, 46, 176-180
Vohra, A.; Satyanarayana, T. (2003), Phytases: microbial sources, production, purification, and potential biotechnological applications. Crit Ver Biotechnol, 23, 29-60.

Wodzinski, R.J.; Ullah, A.H.J. (1996), Phytase. Adv Appl Microbiol, 42, 263-302

Received: February 01, 2010; Revised: August 18, 2010; Accepted: September 21, 2010 